\title{
Proteomic Analysis of Responses to Drought Stress in Sunflower (Helianthus annuus) Leaves by 2DE Gel Electrophoresis and Mass Spectrometry
}

\author{
$\mathrm{M}^{\mathrm{a}}$ Ángeles Castillejo ${ }^{1, *}$, Ana $\mathrm{M}^{\mathrm{a}}$ Maldonado $^{2}$, Samuel Ogueta ${ }^{3}$ and Jesús V. Jorrín ${ }^{2}$
}

\begin{abstract}
${ }^{1}$ Institute of Sustainable Agriculture, IAS-CSIC, Córdoba, Spain; ${ }^{2}$ Agricultural and Plant Biochemistry Research Group, Dept. of Biochemistry and Molecular Biology, University of Córdoba, Campus de Rabanales, Edificio Severo Ochoa (C6), 14071 Córdoba, Spain and ${ }^{3}$ Unidad de Proteómica, SCAI, Ed. Ramón y Cajal, Torre Este $1^{a}$ planta, Campus de Rabanales, Córdoba, Spain.
\end{abstract}

\begin{abstract}
By using a differential proteomic approach, responses to drought stress in sunflower have been studied. Two sunflower genotypes, showing different levels of tolerance to drought have been utilized. Following TCA-acetone protein extraction, the 2-DE leaf protein profile of well watered and drought stressed plants have been compared. Coomassie staining of the gels allowed visualization of around 350 well resolved spots within the 5-8 pH and 10-100 kDa ranges. Image analysis revealed the presence of both, qualitative and quantitative changes between genotypes and treatments. Differential spots were subjected to trypsin digestion and peptides were analyzed by MALDI-TOF mass spectrometry. After database search using peptide mass fingerprinting, 2 genotype-dependent and 23 (susceptible genotype) and 5 (tolerant genotype) stress-responsive protein spots were identified. The two proteins spots differentiating sunflower genotypes corresponded to phosphoglycerate kinase and glyceraldehyde-3-phosphate dehydrogenase. In response to drought conditions a general decrease in protein spots corresponding to enzymes of the photosynthesis and carbohydrate metabolism was observed in the more susceptible genotype, suggesting inhibition of the energetic metabolism. Such changes have not been observed in the tolerant genotype, indicating a normal metabolism under drought stress.
\end{abstract}

Key Words: Differential expression proteomics, drought stress, MALDI-TOF, sunflower proteomics, two-dimensional gel electrophoresis.

\section{INTRODUCTION}

Proteomics is becoming a powerful tool in understanding fundamental processes in plant growth and development. Nevertheless, and unlike human and yeast proteomics, the full potential of proteomics in plant research is still far from being completely exploited. A number of recent reviews summarize and update the contribution of proteomics to basic and practical aspects of the plant biology [1-3]. As well as allowing the characterization of different plant proteomes and the subsequent identification of quite a number of protein species, proteomics may provide clues about crop nutritional values, yield, responses to stresses, and help in identifying key molecular markers for their use in crop improvement by mean of classical plant breeding or biotechnology.

Sunflower (Helianthus annuиs) is the fifth most important source of edible oil after soybean, rapeseed, cotton, and peanut, with a worldwide seed production of 25.8 million tonnes destined almost exclusively to oil extraction, providing $8.2 \%$ of total world volume [4] (FAO, http://www.fao. org/statistics/). Water is a major limiting factor for plant growth and development, and drought is a main cause of yield reduction in crop plants [5]. Hence, the development of

*Address correspondence to this author at the Institute of Sustainable Agriculture, IAS-CSIC, Córdoba, Spain; Tel: + 34957499242; Fax: + 3495749 9252; E-mail: bb2casam@uco.es tolerant crop varieties minimizing these losses is a priority to cope with the increasing food requirements. Although the general effects of drought on plant growth are fairly well known, the primary effects of water deficit at the biochemical and molecular levels are not well understood [6]. For such a purpose, a detailed knowledge at the molecular level of the mechanisms of drought stress early perception, signal transduction and responses is necessary. It is already known that drought responses are multiple and interconnected [7]. Besides, studies in sunflower have revealed that drought tolerance is a complex trait, controlled by factors that affect leaves and roots, and alter physiological aspects of the plant [8].

In this work, using a proteomic approach we aim to analyze the plant response to drought stress in sunflower. By analyzing proteins differentially expressed under stress conditions we intend to gain deeper knowledge of these mechanisms and to identify key proteins and the corresponding genes involved, that could be used as markers in plant breeding programmes. Furthermore, this study will complement previous analyses in which biochemical or transcriptomic approaches have been used $[9,10]$.

Plant responses to stresses, specifically to abiotic stresses, have been the main topic in which differential expression proteomics has been employed [3]. However, unlike the model plant Arabidopsis thaliana and crop rice, proteo- 
mic technology has not, up to date, been used in species that are absent or underrepresented in DNA databases, as in the case of sunflower.

In this work, two sunflower genotypes, displaying different levels of tolerance to drought have been used. The leaf 2DE protein maps of well watered and drought stressed sunflower plants have been compared, and both qualitative and quantitative changes were detected between sunflower genotypes and treatments. After MALDI-TOF mass spectrometry analysis and database search using peptide mass fingerprinting, 2 genotype-dependent, 18 (susceptible genotype) and 3 (tolerant genotype) stress-responsive protein spots were identified, most of them being identified as housekeeping enzymes of the photosynthesis and carbohydrate metabolism. The identity of some of the protein spots was confirmed by tandem mass spectrometry and de novo sequencing.

\section{MATERIALS AND METHODOLOGY}

\section{Sample Preparation}

Sunflower seeds were kindly provided by Dr. A. León (Advanta Semillas, Balcarce, Argentina). Two sunflower genotypes, showing different levels of tolerance to drought have been utilized: susceptible 5257 and tolerant 5270 . Seeds were germinated and plants grown under controlled conditions as reported previously [11]. At the third-leaf developmental stage, a set of plants was subjected to drought stress conditions by limited irrigation $(30 \%$ of the field capacity) while control plants were well watered (100\% of the field capacity). Field capacity can be defined as being the amount of soil moisture or water content held in soil after excess water has drained away.

Plants were irrigated every other day with Hoagland nutrient solution [12]. The $2^{\text {nd }}$ and $3^{\text {rd }}$ pairs of leaves were sampled four and ten days after the beginning of the treatment. Three plants per genotype and treatment were collected, each sample corresponding to four leaves from one individual plant (between 1.5-3.7 g fresh weight). Leaves were abundantly washed with desionized water, dried with filter paper, frozen in liquid nitrogen and stored at $-80^{\circ} \mathrm{C}$ until extraction.

Proteins were extracted by using the TCA-acetone precipitation protocol and quantified with the RCDC protein assay (Bio-Rad) as described [13].

\section{Two-Dimensional Gel Electrophoresis}

Three biological replicates per genotype and treatment were performed, each corresponding to a single plant. Precast $17 \mathrm{~cm}, \mathrm{pH}$ 5-8 linear gradient (Bio-Rad) strips, were rehydrated for $16 \mathrm{~h}$ with $300 \mu \mathrm{l}$ buffer containing $8 \mathrm{M}$ urea, $2 \%$ CHAPS, 20mM DTT, $0.5 \%$ Bio-Lyte (Bio-Rad) and bromophenol blue. $500 \mu \mathrm{g}$ proteins were loaded at the cathodic end of the strips and electrofocussed (Bio-Rad Protean IEF Cell system) at $20^{\circ} \mathrm{C}$ first using a gradually increasing voltage $(250 \mathrm{~V}-10,000 \mathrm{~V})$ and then reaching 50,000 V/h. Following IEF, IPG strips were equilibrated according to Görg et al. [14]. The strips were then transferred onto vertical slab $13 \%$ SDS-polyacrylamide gels (Bio-Rad PROTEAN Plus Dodeca Cell) and electrophoresis run at $50 \mathrm{~mA} / \mathrm{gel}$ until the dye front reached the bottom of the gel. Gels were stained with $\mathrm{CBB}$ G-250 according to the procedure reported by
Mathesius et al. [15]. Gel images were captured with a GS800 imaging densitometer (Bio-Rad), and analyzed with the PDQuest software (Bio-Rad) using ten fold over background as a minimum criterion for presence/absence. The analysis was re-evaluated by visual inspection. Normalized spot volumes (individual spot intensity/normalization factor) calculated for each gel based on total quantity in valid spots were determined, and these values used to designate the significant differentially expressed spots as calculated by Student's $t$-test, $(p \leq 0.05)$. The mean value for the normalized spot volume and the SD were determined for each spot.

\section{MALDI-TOF/TOF Mass Spectrometry and Protein Iden- tification}

Spots from CBB-stained gels were excised automatically (Investigator ProPic, Genomic Solutions), transferred to Multiwell 96 plates and digested with modified porcine trypsin (sequencing grade; Promega) by using a ProGest (Genomics Solution) digestion station. The digestion protocol used was that of Schevchenko et al. [16], with minor variations. Gel plugs were destained by incubation (twice for 30 min) with a solution containing $200 \mathrm{mM}$ ammonium bicarbonate in $40 \%$ acetonitrile at $37^{\circ} \mathrm{C}$, being then subjected to three consecutive dehydratation/rehydration cycles with pure acetonitrile and $25 \mathrm{mM}$ ammonium bicarbonate in $40 \%$ acetonitrile, respectively, and finally dried at room temperature for $10 \mathrm{~min}$. Then, $20 \mu \mathrm{L}$ trypsin, at a concentration of 12.5 $\mathrm{ng} / \mu \mathrm{L}$ in $25 \mathrm{mM}$ ammonium bicarbonate was added to the dry gel pieces and the digestion proceeded at $37^{\circ} \mathrm{C}$ for $12 \mathrm{~h}$. Peptides were extracted from gel plugs by adding $10 \mu \mathrm{L}$ of $1 \%$ (v/v) trifluoracetic acid (TFA) and incubating for $15 \mathrm{~min}$. Samples $(3 \mu \mathrm{l})$ were deposited onto MPep Chips pre-spotted with CHCA (Sunyx, Germany) using the thin layer affinity method [17] according manufacturers instructions, being MS analyzed in a MALDI-TOF/TOF (4700 Proteomics Analyzer, Applied Biosystems) mass spectrometer in the $\mathrm{m} / \mathrm{z}$ range 800 to 4000 , with an accelerating voltage of $20 \mathrm{kV}$. Spectra were internally calibrated with peptides from trypsin autolysis $\left(\mathrm{M}+\mathrm{H}^{+}=842.509, \mathrm{M}+\mathrm{H}^{+}=2211.104\right)$.

The 3 most abundant peptide ions were then subjected to fragmentation analysis, providing information that can be used to determine the peptide sequence.

\section{LC-MS/MS Analysis}

Peptides from digestion were evaporated to dryness, rehydrated in $0.1 \%$ formic acid and subjected to LC-MS/MS analysis. Such analyses were performed using an Ultimate 3000 nanoHPLC system (Dionex, Amsterdam, The Netherlands) in tandem with a 4000 Q-TRAP hybrid triple quadrupole/linear ion trap mass spectrometer (Applied Biosystems) equipped with a nano-ESI source. Samples were concentrated and desalted on a C18 trap column (PepMap C18; Dionex). Peptide separation was achieved on a BioBasic C18, $75 \mu \mathrm{m}$ ID, $10 \mathrm{~cm}$ column (ThermoFisher) using a 30 min linear gradient of $15-40 \%$ acetonitrile vs. $0.1 \%$ formic acid. An electrospray voltage of $3000 \mathrm{~V}$ and a cone voltage of $30 \mathrm{~V}$ were used. Peptide ions detected with a linear ion trap scan were submitted for high resolution scans to determine their charge state and $M_{r}$. MS/MS spectra were acquired in the information dependent acquisition mode. The collision energy was dynamically adjusted according to the charge state and $M_{r}$ of the precursors. 


\section{Protein Identification}

A combined search (MS + MSMS) with the PMF was performed in database of proteins using MASCOT searching engine (Matrix Science Ltd., London; http://www.matrixsci ence.com). A detailed analysis of peptide mass mapping data was performed using GPS Explorer ${ }^{\mathrm{TM}}$ software v 3.5 (Applied Biosystems), allowing the following parameters: specie Viridiplantae, one missed cleavage, $100 \mathrm{ppm}$ mass tolerance, and cysteine carbamidomethylation and methionine oxidation as possible modifications. The confidence in the peptide mass fingerprinting matches was based on the score level and confirmed by the accurate overlapping of the matched peptides with the major peaks of the mass spectrum.

The MS/MS spectra from LC-MS/MS analysis were searched using ProID software (Applied Biosystems), with the aminoacids substitutions threshold parameter set to 1 . Also, cysteine carbamidomethylation as fixed and oxydated methyonine as variable modifications were used. Protein identification significance was judged using the ProID scoring algorithm without taxonomy restrictions and was obtained from MSDB, NCBI and SwissProt protein database. Only proteins matched by a minimum of two peptide sequences with significance higher than $99 \%$ were included in the results list.

\section{RESULTS}

Plant responsive proteins to drought stress have been analyzed in sunflower leaves of two genotypes displaying different level of tolerance: susceptible 5257 and tolerant 5270. Plants were subjected to drought stress by limiting their irrigation (30\% of the field capacity). Fourteen days after the beginning of the treatment, leaf wilting, chlorosis and senescence symptoms were visible in the 5257 susceptible plants, while in the 5270 tolerant plants only a reduction in biomass was detected at later stages (28 days after the beginning of the treatment) (Supplemental material, Fig. 1). Physiological parameters, such as plant height, leaf area and the relative water content were monitored, resulting in statistically significant differences observed 14 days after the beginning of the treatment. Consequently, leaves were sampled four and ten days after the beginning of the treatment, stages at which plants showed no visually stress symptoms.

\section{Two-Dimensional Electrophoresis Protein Profiles Com- parisons}

Analysis of the 2-D gels using the PD-Quest software, followed by visual confirmation, revealed the existence of a number of spots showing qualitative y/or quantitative differences between genotypes or treatments, being these differences manifested four or ten days after the beginning of the treatment. The following criteria were used for considering a spot as being variable: i) consistently present or absent in all three replicates; and ii) display genotype- or treatment-ratios differing in more than 1.5 fold. In total, 53 differential spots fulfilled these criteria (Tables $\mathbf{1}$ and 2). More variable spots were found between control and drought-stressed 5257 plants (28) than between genotypes (17) or between control and drought-stressed 5270 plants (8). A total of 38 quantitative differences were found, which 15 were significant after performing the statistical analysis of data (t-student, $\mathrm{p} \leq 0.05$ ) (Tables 1 and 2).
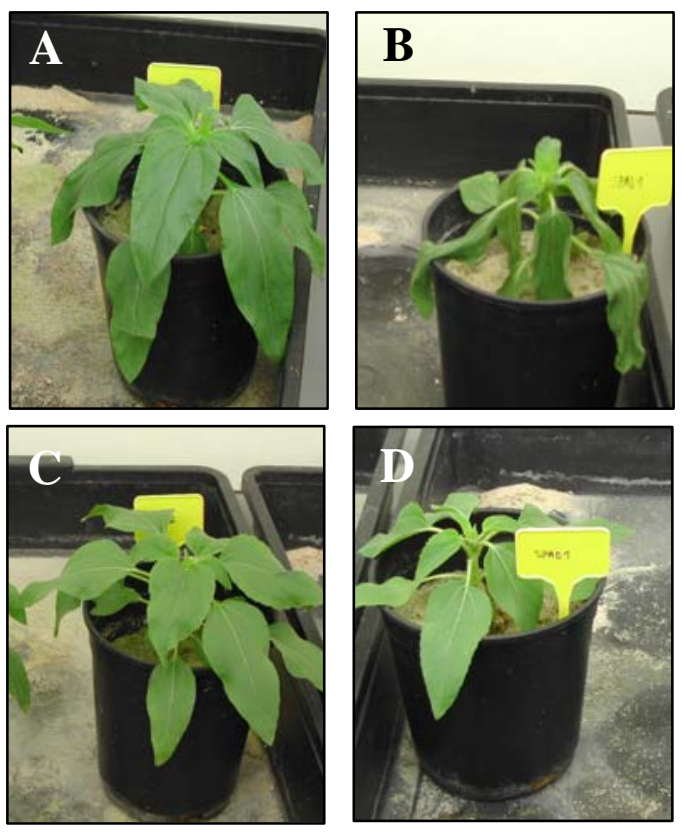

Supplemental Fig. (1). Effect of drought stress in sunflower plants. Pictures were taken 14 days after the beginning of the treatment and corresponded to well watered $(\mathbf{A}, \mathbf{C})$ or drought-stressed $(\mathbf{B}, \mathbf{D})$ plants from the susceptible $5257(\mathbf{A}, \mathbf{B})$ or tolerant 5270 (C, D) genotypes.

\section{Mass Spectrometry and Protein Identification}

The 53 variable spots were subjected to MALDI-TOF mass spectrometry analysis. Protein identification was accomplished by PMF, consulting the MSDB, NCBI and Swiss-Prot databases by using the MASCOT (Matrix Science Ltd., London; http://www.matrixscience.com) algorithm. These searches resulted in 23 hits out of the 53 spots analysed, complying with the following parameters of confidence: i) at least 7 matched peptides (from 7 to 17); ii) sequence coverage of at least 15\% (15-58\%); and iii) minimum score of 60 (60-347) (Table 3).

Out of the 23 identified proteins, 6 matched Helianthus annuus, 10 Arabidopsis thaliana, 3 Nicotiana spp., 1 Solanum tuberosum, 1 Pisum sativum, 1 Flaveria bidentis and 1 Selaginella utahensis sequences.

Because of Helianthus genus genomes and proteomes are not extensively characterized, MS/MS analysis was performed to confirm the identity of those spots that matched successfully in MALDI-TOF analysis (Table 3). MS/MS analysis of the three most abundant ions of each sample was performed in automatic mode. The database searching was carried out combining both spectra, MS and MS/MS, against MSDB, NCBI and SWISS PROT using MASCOT as previously described. Out of the 23 identified spots, 5 were correctly identified by MS/MS (Fig. 4, Table 3), being three of them correctly tested by sequence similarity searching strategy (LC-MS/MS).

In all those cases, the sequence assignation was manually revised to confirm the protein identification. At least, one MS/MS spectrum of each sample was correctly assigned. MS/MS spectra without correct sequence assignation were 
Table 1. Number of Spots Showing Changes between Genotypes or Treatments*

\begin{tabular}{|c|c|c|c|c|c|}
\hline & \multicolumn{3}{|c|}{ Number of Differential Spots } & \multicolumn{2}{|c|}{ Identified Spots } \\
\hline & Total & Quantitative & Qualitative & Total Number & Spot Number (d) \\
\hline Genotype + Treatments & 53 & $38(15)$ & 15 & 23 & \\
\hline Genotypes 5257/5270 & 17 & $\begin{array}{r}10(6): \\
4 \boldsymbol{\Lambda}, 6 \boldsymbol{\nabla}\end{array}$ & $\begin{array}{l}7: \\
7 \text { (a) }\end{array}$ & 2 & 7,12 \\
\hline 5257 genotype & 28 & $\begin{array}{c}22(6): \\
5 \boldsymbol{\Lambda}, 17 \boldsymbol{\nabla}\end{array}$ & $\begin{array}{c}6: \\
1(b), 5(c)\end{array}$ & 18 & $\begin{array}{c}18,21,23,25,26 \\
30-38,40-43\end{array}$ \\
\hline 5270 genotype & 8 & $\begin{array}{c}6(3): \\
5 \boldsymbol{\Lambda}, 1 \boldsymbol{\nabla}\end{array}$ & $\begin{array}{c}2: \\
1(\mathrm{~b}), 1(\mathrm{c})\end{array}$ & 3 & $48,52,53$ \\
\hline
\end{tabular}

*The following criteria were used to consider a spot as being variable: i) consistently present or absent in all the three replicates; ii) display ratios between genotypes or treatment higher than 1.5. In parenthesis is shown the number of spots presenting statistically significant quantitative differences $(p \leq 0.05)$.

$\boldsymbol{\Lambda}$, increase; $\boldsymbol{\nabla}$, decrease; (a), spots non detected in 5270; (b), spots non detected in control plants; (c), spots non detected under drought conditions; (d), spot number according to Table 2 and Figs. (1-3).

manually de novo sequenced and protein identification was confirmed by BLAST analysis (Table 3).

\section{Functional Classification of the Proteins}

Proteins identified by PMF corresponded to: i) protein/enzymes of the photosynthesis, including photosystem II oxygen-evolving complex protein 1 precursor (spot 25), carbonic anhydrase chloroplast precursor (spots 26 and 36), ribulose-1,5-bisphosphate carboxylase/oxygenase large subunit (spots 23, 38, 42 and 53) and small (spots 30), ferredoxin-NADP+ reductase (spot 35 ); ii) enzymes of the glycolisis/gluconeogenesis pathway, including 2-phospho-Dglycerate hydroylase (spot 48), phosphoglycerate kinase, chloroplast precursor (spots 7 and 31), glyceraldehyde-3phosphate dehydrogenase (NADP) (phosphorylating) B, chloroplast (spots 12 and 37), probable fructose-bisphosphate aldolase precursor, chloroplast (spots 21 and 34); iii) enzymes of the glyoxylate cycle (glyoxalase I, spot 33); iv) redox and oxygen-stress related enzymes, including quinone oxidoreductase-like protein (spot 18 ), $\mathrm{Cu} / \mathrm{Zn}$ superoxide dismutase (spot 43), and L-ascorbate peroxidase (spot 52). The remaining three spots corresponded to unidentified hypothetical proteins (spots 32 and 40), and one alpha-soluble NSF attachment protein (spot 41) (Table 3).

\section{Differences between Genotypes}

Out of the 17 spots differentially present in both genotypes, seven were unique to $5257(1,3,5,10,11,16$ and 17) and 10 quantitative, with four of them being present at higher (spots 4, 12, 13, and 14) and two spots in a lesser (spots 8 and 9) amount in 5257 leaf extracts (Table 2). MS analysis and database search resulted in the identification of two spots: phosphoglycerate kinase (spot 7) and glyceraldehyde-3-phosphate dehydrogenase (spot 12).

\section{Drought Responsive Proteins}

Drought conditions caused changes in the leaf 2-DE protein profile of both 5257 and 5270 plants. In the more sus- ceptible 5257 genotype, out of the 28 changes observed, six were qualitative, and 22 quantitative. In genotype 5257, as a general rule, a decrease in the intensity of the spots was observed (17 out of the 28) with five of them disappearing while only one newly appeared. This decrease was observed for spots identified as photosynthetic protein/enzymes: photosystem II oxygen-evolving complex protein 1 precursor (spot 25, 4 days), carbonic anhydrase (spots 26 and 36, 4 and 10 days), RubisCO large and small subunits (spots 23, 38 and 42,4 and 10 days), ferredoxin-NADP+ reductase (spot 35, 10 days), those of the glycolysis/gluconeogenesis: phosphoglycerate kinase (spot 31, 10 days), glyceraldehyde-3phosphate dehydrogenase (spot 37, 10 days), aldolase (spots 21 and 34, 4 and 10 days), and proteins involved in different functions, including : glyoxalase (spot 33, 10 days), superoxide dismutase (spot 43, 10 days).

When plants of the tolerant genotype 5270 were analysed, only eight differential spots were observed in response to stress, a much smaller figure than the one obtained for susceptible plants. Two of them corresponded to qualitative changes (one appears upon stress application, while the other disappears), and the remaining six spots were quantitative differences. Differently from the susceptible plants, only two spots corresponding to photosynthetic/carbohydrate metabolism enzymes were observed: RubisCO large subunit (spot 53) and a phosphoglycerate hydroylase (spot 48), increasing at 10 and 4 days after stress application, respectively. Other spot identified corresponded to an L-ascorbate peroxidase (spot 48) that decreased at day 10.

\section{DISCUSSION}

The protein profile of sunflower leaf tissue was analyzed by two-dimensional gel electrophoresis. Hence, the present study is limited, according to the methodology used, to just a small fraction of the whole proteome, determined by the TCA-acetone precipitation extraction protocol and the 2-DE separation technique utilized, the hydrophobic-membrane, minor and extreme $\mathrm{p} I$ proteins being underrepresented. Previous experiments revealed that most of the solubilised pro- 
Table 2. Spots Showing Changes between Genotypes or Treatments*

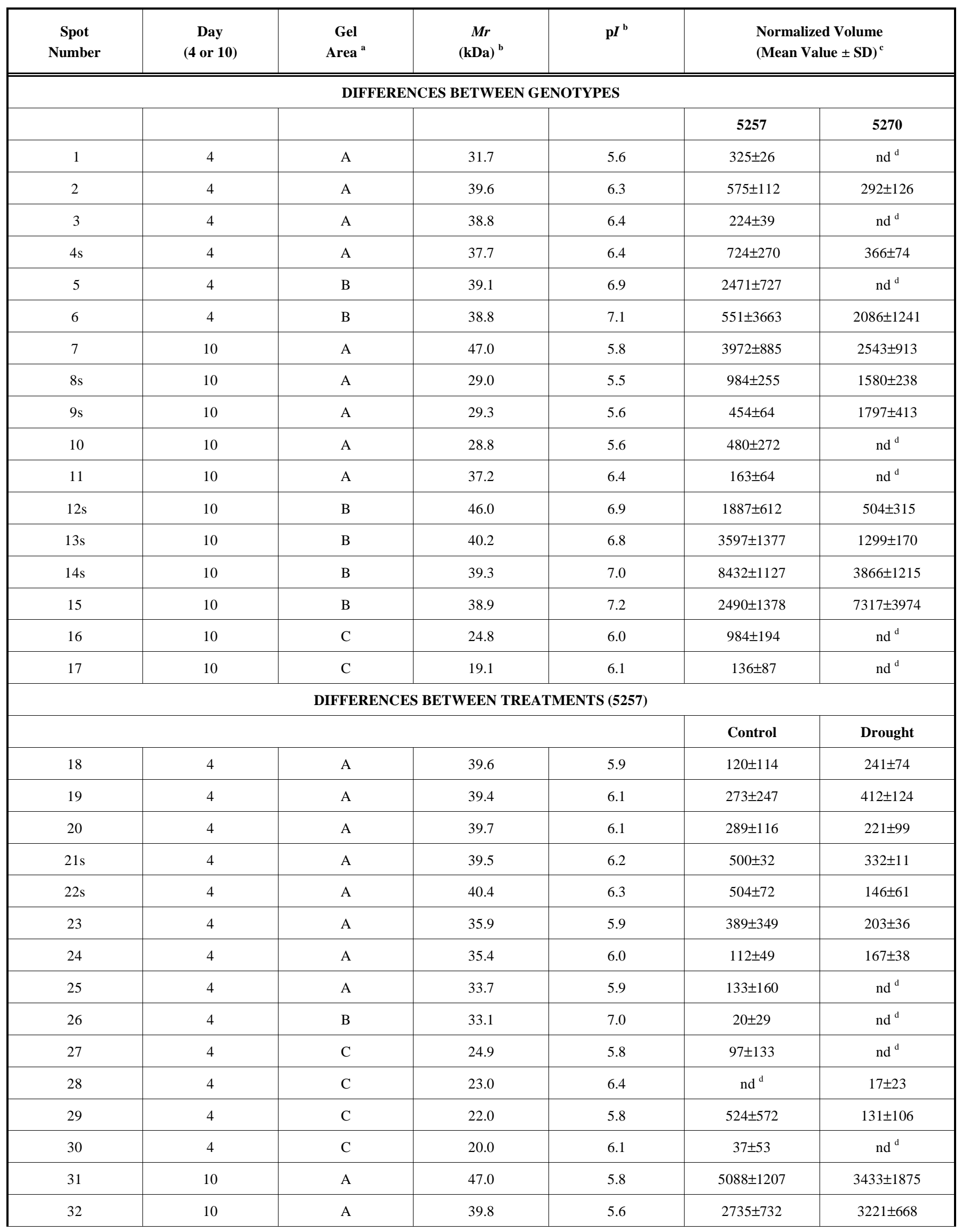


(Table 2) contd....

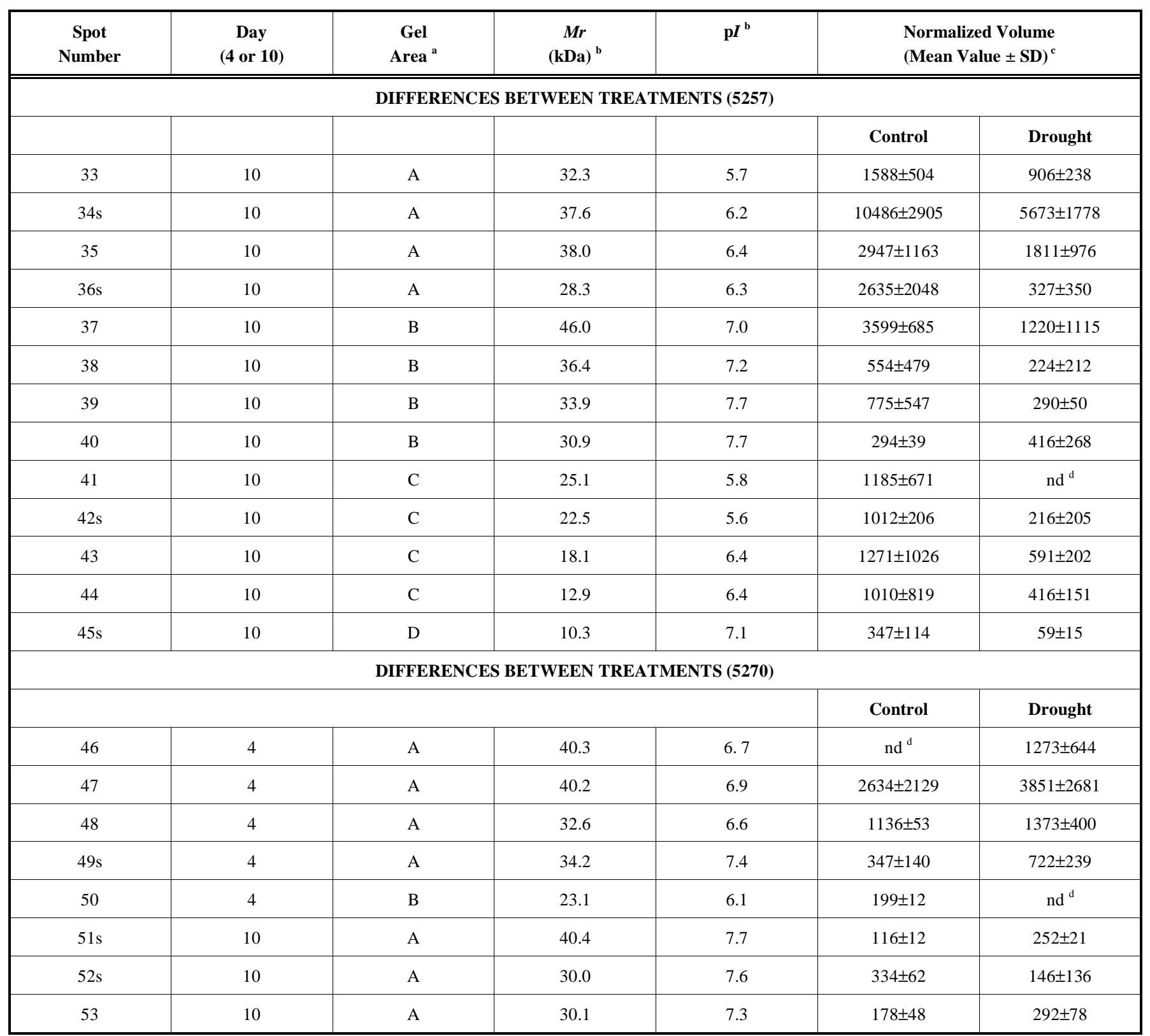

*The following criteria were used to consider a spot as being variable: i) consistently present or absent in all the three replicates; ii) display ratios between genotypes or treatment higher than 1.5.; $\mathrm{s}$, indicates quantitative differences statistically significant ( $t$-Student $p \leq 0.05$ ).

a. As indicated in Figs. (1-3).

b. Calculated with standard molecular weight markers $(M r)$ and the PD-Quest software $(\mathrm{p} I)$.

c. Normalized volume values as calculated by the PD-Quest software are mean \pm standard deviation (SD) of three independent replicates.

nd, non-detected.

teins resolved well in the 5-8 $\mathrm{pH}$ and $10-100 \mathrm{kDa} \mathrm{Mr}$ range, determining the use of 5-8 IEF strips for this analysis (Supplemental material, Fig. 2). This distribution pattern has been observed in leaf tissue from other plant species [18]; on the contrary, and when using the same strategy, root proteins concentrated in the 4-7 $\mathrm{pH}$ range $[19,20]$.

Following CBB staining of the gels, an average of 350 spots was resolved, this figure being within the range observed for leaves of other plant species analyzed [13, 18]. The 2-DE pattern was quite reproducible in the three replicates of the same treatment, and at least 250 spots were commonly represented in all of them (genotype or treatment)
(Figs. 1-3). Proteins differentially expressed between genotypes/treatments were subjected to two-dimensional gel electrophoresis and mass spectrometry.

Out of the 53 analysed proteins spots, only 23 could be matched against MSDB, NCBI and Swiss-Prot databases. This low percentage of identified proteins is typical of those species which are absent or underrepresented in public databases. The MS/MS results showed that some of identified proteins had a high homology with those from other plant species, because the aminoacidic sequence were identical. The use of either de novo sequencing followed by BLAST sequence similarity searching against multiple databases or 
Table 3. List of Identified Proteins* Classified According to their Function

\begin{tabular}{|c|c|c|c|c|c|c|c|c|c|}
\hline $\begin{array}{l}\text { Spot } \\
\text { No. }{ }^{a}\end{array}$ & Protein Name & $\begin{array}{c}\text { Plant Species } \\
\text { Accession Number } \\
\text { from Database }\end{array}$ & $\begin{array}{c}\mathrm{Mr} / \mathrm{pI}^{\mathrm{b}} \\
\text { Experimental } \\
\text { (Theoretical) }\end{array}$ & $\begin{array}{l}\text { Matched } \\
\text { Peptides }\end{array}$ & Score & $\begin{array}{c}\% \\
\text { Coverage }\end{array}$ & Peptide Sequence $^{\mathrm{c}}$ & $\begin{array}{c}\text { LC-MS/MS Analysis } \\
\text { Accession No.; Specie; } \\
\text { Charge State; Amino Acid } \\
\text { No.; (Score) }{ }^{\text {d }} \text { Peptide } \\
\text { Sequence }\end{array}$ & Feature $^{e}$ \\
\hline 18 & $\begin{array}{l}\text { Quinone oxidoreduc- } \\
\text { tase-like protein }\end{array}$ & $\begin{array}{l}\text { Helianthus } \\
\text { annuus } \\
\text { Q94F67 }\end{array}$ & $\begin{array}{c}39.6 / 5.9 \\
(33.2 / 4.8)\end{array}$ & 11 & 93 & 33 & - & - & $\begin{array}{l}4 \text { days } \\
5257 \\
\mathrm{C} / \mathrm{D} \uparrow\end{array}$ \\
\hline 43 & $\begin{array}{l}\mathrm{Cu} / \mathrm{Zn} \text { superoxide } \\
\text { dismutase }\end{array}$ & $\begin{array}{l}\text { Helianthus } \\
\text { annuus } \\
\text { Q6A199 }\end{array}$ & $\begin{array}{c}18.1 / 6.4 \\
(15.5 / 5.6)\end{array}$ & 9 & 114 & 54 & - & - & $\begin{array}{c}10 \text { days } \\
5257 \\
\mathrm{C} / \mathrm{D} \downarrow\end{array}$ \\
\hline \multicolumn{10}{|c|}{ Metabolism (primary carbon metabolism) } \\
\hline 7 & $\begin{array}{c}\text { Phosphoglycerate } \\
\text { kinase. Chloroplast } \\
\text { precursor }\end{array}$ & $\begin{array}{l}\text { Arabidopsis } \\
\text { thaliana } \\
\text { P50318 }\end{array}$ & $\begin{array}{c}47.0 / 5.8 \\
(50.0 / 6.1)\end{array}$ & 15 & 125 & 40 & - & - & $\begin{array}{c}10 \text { days } \\
5257 / 5270 \downarrow\end{array}$ \\
\hline 12 & $\begin{array}{c}\text { Glyceraldehyde-3- } \\
\text { phosphate dehydro- } \\
\text { genase (NADP) (phos- } \\
\text { phorylating) B. Chlo- } \\
\text { roplast }\end{array}$ & $\begin{array}{l}\text { Nicotiana } \\
\text { tabacum } \\
\text { AAA34076 }\end{array}$ & $\begin{array}{c}46.0 / 7.0 \\
(42.2 / 8.7)\end{array}$ & 12 & 80 & 31 & - & - & $\begin{array}{c}10 \text { days } \\
5257 / 5270 \downarrow\end{array}$ \\
\hline 33 & Glyoxalase I & $\begin{array}{l}\text { Arabidopsis } \\
\text { thaliana } \\
\text { Q8LEY7 }\end{array}$ & $\begin{array}{c}32.3 / 5.7 \\
(39.5 / 7.0)\end{array}$ & 12 & 85 & 37 & - & - & $\begin{array}{c}10 \text { days } \\
5257 \\
\mathrm{C} / \mathrm{D} \downarrow\end{array}$ \\
\hline 34 & $\begin{array}{c}\text { Fructose-bisphosphate } \\
\text { aldolase precursor. } \\
\text { Chloroplast }\end{array}$ & $\begin{array}{c}\text { Pisum } \\
\text { sativum } \\
\text { Q01517 }\end{array}$ & $\begin{array}{c}37.6 / 6.2 \\
(38.0 / 5.5)\end{array}$ & 7 & 131 & 15 & $\begin{array}{l}\text { EAAWGLAR } \\
\text { SAAYYQQGAR }\end{array}$ & $\begin{array}{c}\text { P16096 } \\
\text { Spinacia oleracea; +2; } \\
\text { 34-45 (2.2) } \\
\text { FTPSGSSSLTVR }\end{array}$ & $\begin{array}{c}10 \text { days } \\
5257 \\
\mathrm{C} / \mathrm{D} \downarrow\end{array}$ \\
\hline 37 & $\begin{array}{c}\text { Glyceraldehyde-3- } \\
\text { phosphate dehydro- } \\
\text { genase (NADP) (phos- } \\
\text { phorylating) B. Chlo- } \\
\text { roplast }\end{array}$ & $\begin{array}{c}\text { Nicotiana } \\
\text { tabacum } \\
\text { AAA34076 }\end{array}$ & $\begin{array}{c}46.0 / 7.0 \\
(47.2 / 8.7)\end{array}$ & 12 & 81 & 31 & $\begin{array}{c}\text { GITAEDVNAAFR } \\
\text { VPTPNVSVVDL } \\
\text { VVNVAK }\end{array}$ & $\begin{array}{c}\text { P09044 } \\
\text { Nicotiana tabacum; }+2 ; \\
\text { 308-319 }(8.2) \\
\text { GITAEDVNAAFR }\end{array}$ & $\begin{array}{c}10 \text { days } \\
5257 \\
\mathrm{C} / \mathrm{D} \downarrow\end{array}$ \\
\hline 48 & $\begin{array}{l}\text { 2-phospho-D- } \\
\text { glycerate hydroylase }\end{array}$ & $\begin{array}{l}\text { Arabidopsis } \\
\text { thaliana } \\
\text { Q9ZW34 }\end{array}$ & $\begin{array}{c}32.6 / 6.6 \\
(51.6 / 5.3)\end{array}$ & 13 & 68 & 34 & - & - & $\begin{array}{l}4 \text { days } \\
5270 \\
\mathrm{C} / \mathrm{D} \uparrow\end{array}$ \\
\hline \multicolumn{10}{|c|}{ Photosynthesis } \\
\hline 23 & $\begin{array}{c}\text { Ribulose-1.5-bisphos- } \\
\text { phate carboxylase/oxy- } \\
\text { genase large subunit }\end{array}$ & $\begin{array}{l}\text { Selaginella } \\
\text { utahensis } \\
\text { Q8HSV5 }\end{array}$ & $\begin{array}{c}35.9 / 5.9 \\
(50.0 / 7.7)\end{array}$ & 10 & 74 & 23 & - & - & $\begin{array}{l}4 \text { days } \\
5257 \\
\mathrm{C} / \mathrm{D} \downarrow\end{array}$ \\
\hline
\end{tabular}


(Table 3) contd....

\begin{tabular}{|c|c|c|c|c|c|c|c|c|c|}
\hline \multirow[b]{2}{*}{$\begin{array}{l}\text { Spot } \\
\text { No. }{ }^{a}\end{array}$} & \multirow[b]{2}{*}{ Protein Name } & \multicolumn{6}{|c|}{ MS+MS/MS Analysis (MALDI-TOF/TOF) } & \multirow{2}{*}{$\begin{array}{c}\text { LC-MS/MS Analysis } \\
\text { Accession No.; Specie; } \\
\text { Charge State; Amino Acid } \\
\text { No.; (Score) }{ }^{\mathrm{d}} \text { Peptide } \\
\text { Sequence }\end{array}$} & \multirow[b]{2}{*}{ Feature ${ }^{e}$} \\
\hline & & $\begin{array}{c}\text { Plant Species } \\
\text { Accession Number } \\
\text { from Database }\end{array}$ & $\begin{array}{c}\text { Mr/pI }{ }^{\mathrm{b}} \\
\text { Experimental } \\
\text { (Theoretical) }^{\text {The }}\end{array}$ & $\begin{array}{l}\text { Matched } \\
\text { Peptides }\end{array}$ & Score & $\begin{array}{c}\% \\
\text { Coverage }\end{array}$ & Peptide Sequence $^{c}$ & & \\
\hline \multicolumn{10}{|c|}{ Photosynthesis } \\
\hline 25 & $\begin{array}{c}\text { Photosystem II oxygen- } \\
\text { evolving complex } \\
\text { protein } 1 \text { precursor }\end{array}$ & $\begin{array}{c}\text { Arabidopsis } \\
\text { thaliana } \\
\text { P23321 }\end{array}$ & $\begin{array}{c}33.7 / 5.9 \\
(35.3 / 5.7)\end{array}$ & 17 & 64 & 46 & - & - & $\begin{array}{l}4 \text { days } \\
5257 \\
\mathrm{C} / \mathrm{D} \infty\end{array}$ \\
\hline 26 & $\begin{array}{l}\text { Carbonic anhydrase. } \\
\text { Chloroplast precursor }\end{array}$ & $\begin{array}{l}\text { Arabidopsis } \\
\text { thaliana } \\
\text { P27140 }\end{array}$ & $\begin{array}{c}33.1 / 7.0 \\
(29.8 / 5.4)\end{array}$ & 7 & 60 & 32 & - & - & $\begin{array}{l}4 \text { days } \\
5257 \\
C / D \infty\end{array}$ \\
\hline 30 & $\begin{array}{c}\text { Ribulose-bisphosphate } \\
\text { carboxylase small chain } \\
\text { precursor }\end{array}$ & $\begin{array}{l}\text { Helianthus } \\
\text { annuus } \\
\text { P08705 }\end{array}$ & $\begin{array}{c}20.0 / 6.1 \\
(20.5 / 9.1)\end{array}$ & 7 & 72 & 30 & - & - & $\begin{array}{l}4 \text { days } \\
5257 \\
\text { C/D } \infty\end{array}$ \\
\hline 36 & $\begin{array}{l}\text { Carbonic anhydrase. } \\
\text { Chloroplast precursor }\end{array}$ & $\begin{array}{l}\text { Flaveria bidentis } \\
\text { P46510 }\end{array}$ & $\begin{array}{c}28.3 / 6.3 \\
(35.9 / 5.8)\end{array}$ & 6 & 97 & 24 & $\begin{array}{c}\text { EAVNVSLGNLL } \\
\text { TYPFVR } \\
\text { VRCPSHVLDFQ } \\
\text { PGEAFVVR }\end{array}$ & $\begin{array}{c}\text { P46510 } \\
\text { Flaveria bidentis; }+2 ; \\
\text { 184-196 (2.0) } \\
\text { NVANMVPPFDKTK }\end{array}$ & $\begin{array}{l}10 \text { days } \\
5257 \\
\mathrm{C} / \mathrm{D} \downarrow\end{array}$ \\
\hline 38 & $\begin{array}{c}\text { Ribulose-1.5-bisphos- } \\
\text { phate carboxylase/oxy- } \\
\text { genase large subunit }\end{array}$ & $\begin{array}{l}\text { Helianthus } \\
\text { annuus } \\
\text { Q9ZSR9 }\end{array}$ & $\begin{array}{c}36.4 / 7.2 \\
(54.3 / 5.9)\end{array}$ & 15 & 106 & 40 & - & - & $\begin{array}{l}10 \text { days } \\
5257 \\
\mathrm{C} / \mathrm{D} \downarrow\end{array}$ \\
\hline 42 & $\begin{array}{c}\text { Ribulose-1.5-bisphos- } \\
\text { phate carboxylase/oxy- } \\
\text { genase large subunit }\end{array}$ & $\begin{array}{l}\text { Helianthus } \\
\text { annuus } \\
\text { P45738 }\end{array}$ & $\begin{array}{c}22.5 / 5.6 \\
(54.3 / 5.9)\end{array}$ & 6 & 76 & 20 & TFDGPPHGIQVER & - & $\begin{array}{l}10 \text { days } \\
5257 \\
\mathrm{C} / \mathrm{D} \downarrow\end{array}$ \\
\hline 53 & $\begin{array}{c}\text { Ribulose-1.5-bisphos- } \\
\text { phate carboxylase/oxy- } \\
\text { genase large subunit }\end{array}$ & $\begin{array}{l}\text { Helianthus } \\
\text { annuus } \\
\text { Q9ZSR9 }\end{array}$ & $\begin{array}{c}30.1 / 7.3 \\
(53.8 / 5.9)\end{array}$ & 16 & 128 & 35 & - & - & $\begin{array}{l}10 \text { days } \\
5270 \\
\mathrm{C} / \mathrm{D} \uparrow\end{array}$ \\
\hline \multicolumn{10}{|c|}{ Energy Metabolism } \\
\hline 35 & $\begin{array}{l}\text { Ferredoxin-NADP+ } \\
\text { reductase }\end{array}$ & $\begin{array}{c}\text { Arabidopsis } \\
\text { thaliana } \\
\text { Q9FKW6 }\end{array}$ & $\begin{array}{c}38.0 / 6.4 \\
(40.6 / 8.3)\end{array}$ & 12 & 69 & 36 & - & - & $\begin{array}{l}10 \text { days } \\
5257 \\
\mathrm{C} / \mathrm{D} \downarrow\end{array}$ \\
\hline \multicolumn{10}{|c|}{ Cellular transport } \\
\hline 41 & $\begin{array}{l}\text { Alpha-soluble NSF } \\
\text { attachment protein }\end{array}$ & $\begin{array}{l}\text { Solanum } \\
\text { tuberosum } \\
\text { Q9M5P8 }\end{array}$ & $\begin{array}{c}25.1 / 5.8 \\
(32.9 / 5.1)\end{array}$ & 12 & 60 & 58 & - & - & $\begin{array}{l}10 \text { days } \\
5257 \\
\mathrm{C} / \mathrm{D} \infty\end{array}$ \\
\hline \multicolumn{10}{|c|}{ Unknown } \\
\hline 32 & $\begin{array}{c}\text { Hypothetical protein } \\
\text { T1008.150 }\end{array}$ & $\begin{array}{l}\text { Arabidopsis } \\
\text { thaliana } \\
\text { Q9M030 }\end{array}$ & $\begin{array}{l}39.8 / 5.6 \\
(36.7 / 9.6)\end{array}$ & 9 & 63 & 37 & - & - & $\begin{array}{l}10 \text { days } \\
5257 \\
\mathrm{C} / \mathrm{D} \uparrow\end{array}$ \\
\hline 40 & $\begin{array}{c}\text { Hypothetical protein } \\
\text { T20K12.110 }\end{array}$ & $\begin{array}{l}\text { Arabidopsis } \\
\text { thaliana } \\
\text { Q9M2E3 }\end{array}$ & $\begin{array}{c}30.9 / 7.7 \\
(29.5 / 8.8)\end{array}$ & 8 & 62 & 38 & - & - & $\begin{array}{l}10 \text { days } \\
5257 \\
\mathrm{C} / \mathrm{D} \uparrow\end{array}$ \\
\hline
\end{tabular}

* The MASCOT algorithm and the MSDB, NCBI and Swiss-Prot databases were consulted.

a. As indicated in Figs. (1-3) and Table 2.

b. Calculated with standard molecular weight markers $(M r)$ and the PD-Quest software $(\mathrm{p} I)$.

c. Theoretical sequence from MSDB, NCBI and SWISS-PROT database.

d. Score $99 \%$ confidence: $\geq 2.0$.

e. Indicate sampling time, genotype $(5257,5270)$, treatment (C, control; D, drought) and the ratio between the genotypes and treatments; $\uparrow$, increase, $\downarrow$, decrease; $\infty$, non detected in 


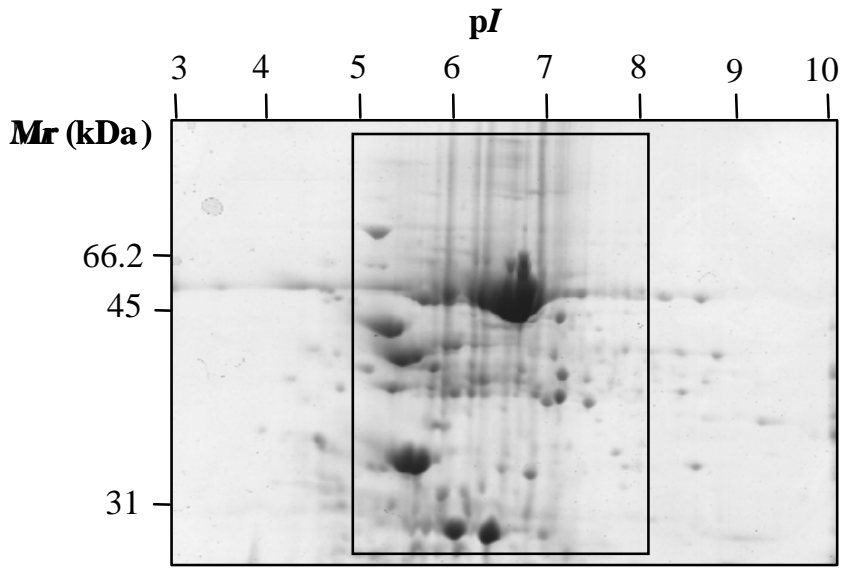

Supplemental Fig. (2). 2-DE protein profile of CBB-stained gels. A representative gel in the $3-10 \mathrm{pH}$ range is shown, corresponding to leaf extracts from well watered plants (genotype 5257). Most proteins were concentrated in the 5 to $8 \mathrm{pH}$ range.

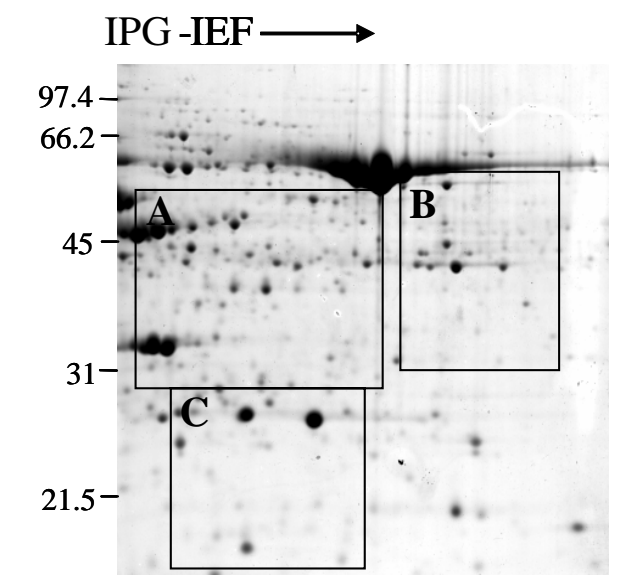

sequence similarity searching strategy is a viable strategy to obtain protein identifications in species where neither the genome nor the proteome have been extensively characterized.

In some cases spots excised from different gels corresponding to the conditions studied (genotypes and treatments) were identified as being the same protein. Those include spots 26 and 36 (carbonic anhydrase), 23, 38, 42 and 53 (RubisCO large subunit), 30 (RubisCO small subunit), 7 and 31 (phosphogycerate kinase), 12 and 37 (glyceraldehyde-3-phosphate dehydrogenase), 21 and 34 (fructosebisphosphate aldolase). When comparing these spots hitting the same protein, there was a close similarity between experimental and theoretical $M r$ and $\mathrm{p} I$ values for carbonic anhydrase (26 and 36), phosphoglycerate kinase (7 and 31), glyceraldehyde-3- phosphate dehydrogenase (12 and 37), and aldolase (21 and 34). On the contrary, significant differences were observed for either $M r, \mathrm{p} I$, or both, experimental
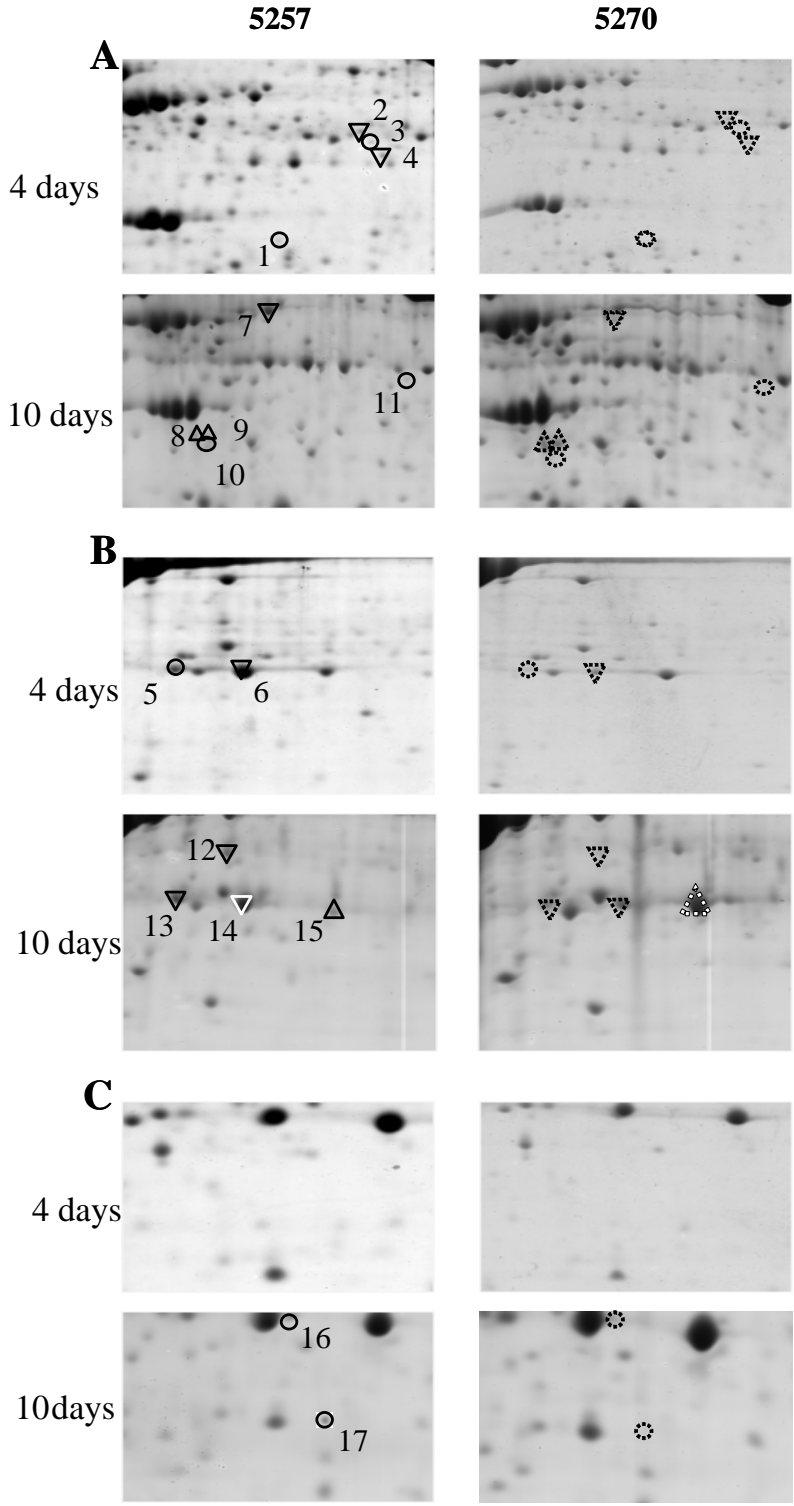

Fig. (1). Comparison of the leaf 2-DE protein profile between well watered control plants of 5257 and 5270 genotypes. A representative gel corresponding to genotype 5257 at day 4 (left) has been divided into areas, $\mathbf{A}, \mathbf{B}$, and $\mathbf{C}$, which are displayed in detail (right). Spots differentiating genotypes have been numbered. Qualitative changes (presence/absence) are surrounded by circles and quantitative changes by triangles (increase) and reversed triangles (decrease). 

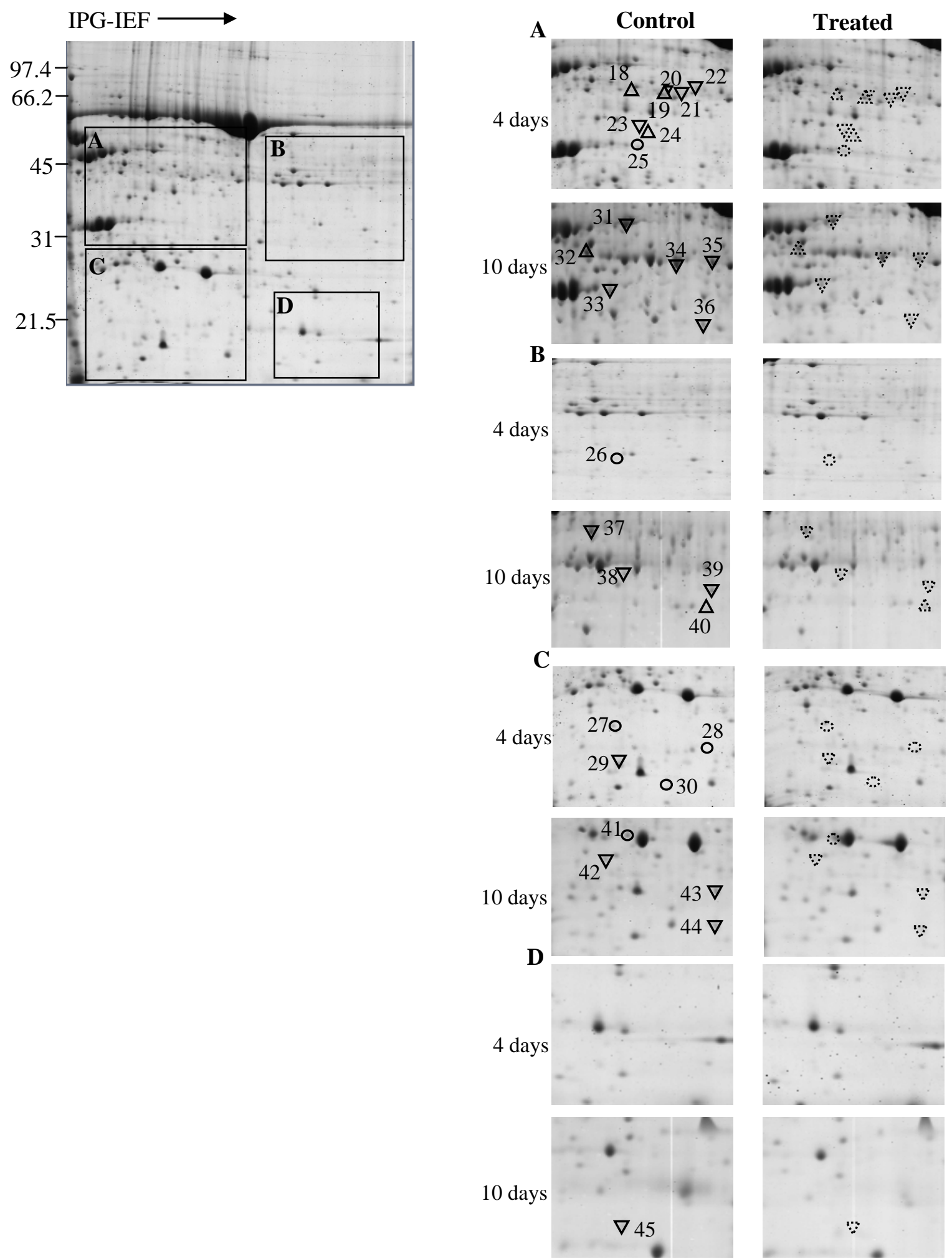

Fig. (2). Comparison of the leaf 2-DE protein profile between control and drought-stressed 5257 plants. A representative gel corresponding to control plants taken at day 4 (left), has been divided into areas, $\mathbf{A}, \mathbf{B}, \mathbf{C}$, and $\mathbf{D}$, which are displayed in detail (right). Spots showing differences under stress treatments have been numbered. Qualitative changes (presence/absence) are surrounded by circles and quantitative changes by triangles (increase) and reversed triangles (decrease).

and theoretical values for RubisCO large $(23,38,42,53)$ and small (30) subunits. These differences can be interpreted in terms of protein degradation (lower experimental than theoretical $M r$ values, as in example RubisCO large subunit), or may account for different pos-translational protein species (different $\mathrm{p} I$, as in example RubisCO small subunit). The identification of spots displaying different values for experimental $\mathrm{Mr}$ and/or $\mathrm{pI}$, as RubisCO large or small subunits has been reported previously when analysing leaf extracts from different plant species, especially under stress conditions [21]. 

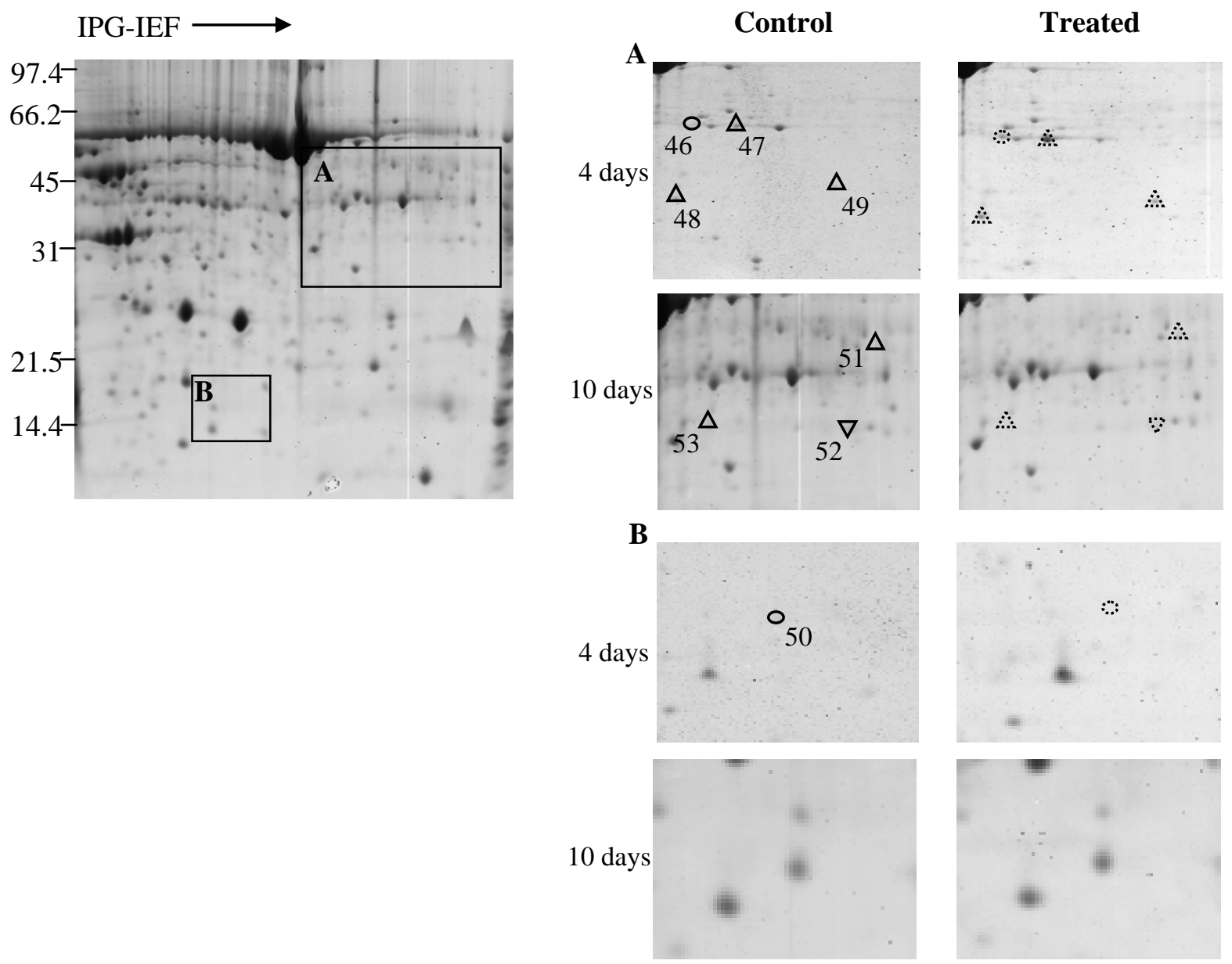

Fig. (3). Comparison of the leaf 2-DE protein profile between control and drought-stressed 5270 plants. A representative gel corresponding to control plants taken at day 4 (left) has been divided into areas A and B which are displayed in detail (right). Spots showing differences under stress treatments have been numbered. Qualitative changes (presence/absence) are surrounded by circles and quantitative changes by triangles (increase) and reversed triangles (decrease).

Between the two non-inoculated genotypes, protein difference matched to metabolism proteins: phosphoglycerate kinase and glyceraldehyde-3-phosphate dehydrogenase. These results are in agreement with the usefulness of 2-DE proteomic approach for cataloguing genotypes that have already been reported [21, 22]. In any case, to definitively prove this utility, a more comprehensive analysis including more genotypes needs to be done. The biological interpretation of the differences observed is a matter of speculation, although it could be related to differences in the efficiency in energy utilization for growth and fitness purposes.

The proteins patterns of the two genotypes were then analysed in response to drought condition. In the more susceptible 5257 genotype a decrease was observed for spots identified as photosynthetic and glycolysis/gluconeogenesis protein/enzymes. In view of these results we can affirm that, as a clear trend, there is a decrease in enzymes of the photosynthesis and glycolysis/gluconeogenesis pathways, this being manifested at both the earlier (4 days) and later (10 days) time sampling in the susceptible plants.

In drought susceptible plants, withholding water reduces the rate of photosynthesis [23, 24], which, in turn causes lower biomass yields. This reduction could be explained, at least partly, by a decrease in the amount of RubisCO and other proteins involved in photosynthesis $[18,25]$ by, among other mechanisms, proteolysis occurring in drought stressed plants, as it has been reported in rice and sugar beet plants $[25,26]$.

Only a few of the plant proteomic studies published up to date have dealt with drought stress responses [21, 25-31]. The drought responsive proteins identified and the nature of the change (increase or decrease) differ among assays. These differences can be justified not only by the plant species, tissue or organ under study, but also by the level (more or less severe) and length of the of stress, whether it is gradually or rapidly applied and sampling times (changes related to early or late responses) [32,33]. Changes in the following proteins identified in this study have been previously reported in response to water deficit: carbonic anhydrase [34, 35], oxygen evolving [36], RubisCO [27], phosphoglycerate kinase and glyceraledyhde-3-phosphate dehydrogenase [37], further reinforcing the involvement of these proteins during drought response.

\section{CONCLUSION}

According to the data presented here, we can conclude that photosynthesis and carbohydrate metabolism, and hence energy production, functions normally in the tolerant plants, 
4700 MS/MS Precursor 1263.63 Spec \#1 MC[BP = 1263.6, 852]

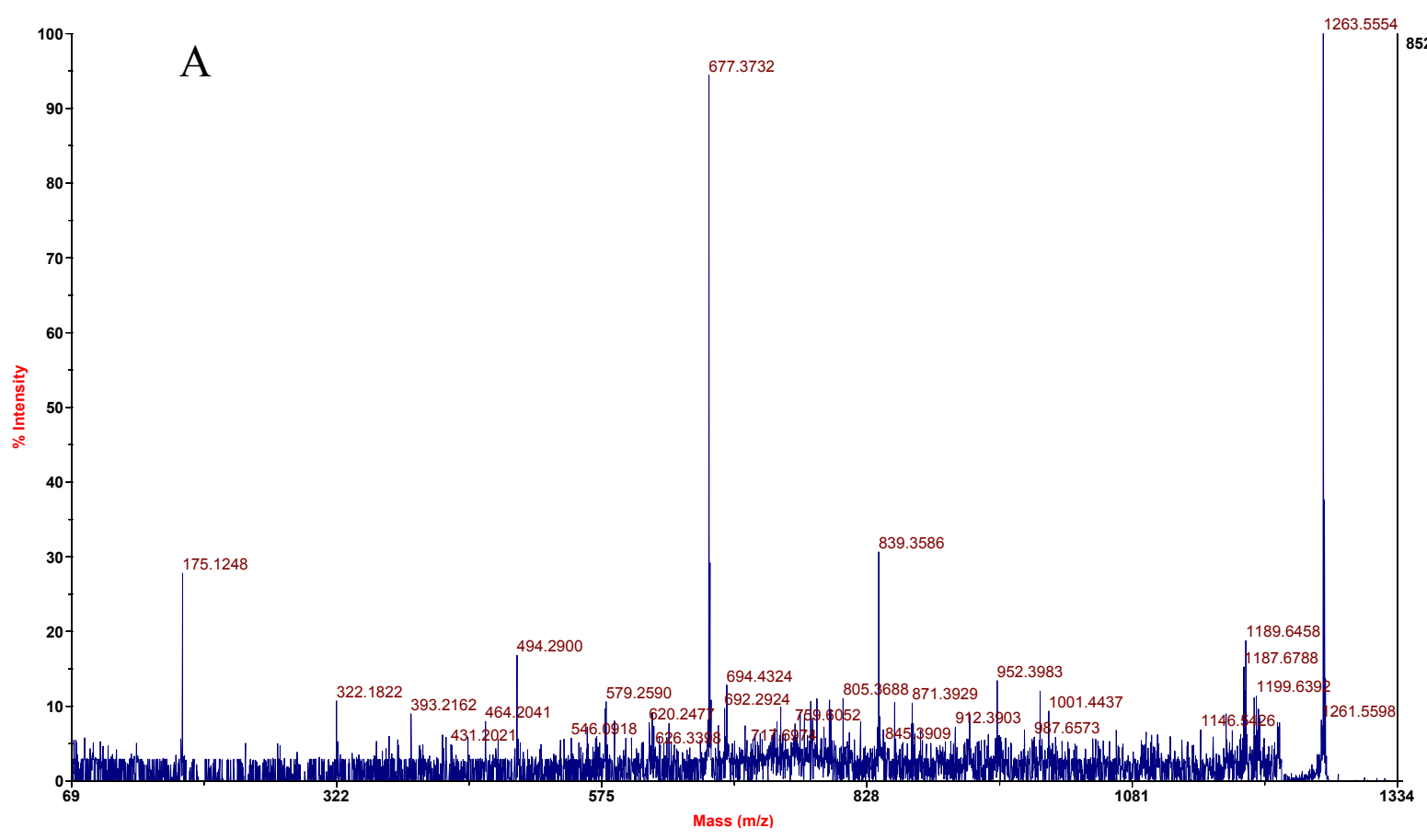

+EP (63238) Charge (+2) CE(36.6191) FT (100): Exp 4, 26.470 to26.562 min from Sample 1 (Sample001) of MAngeles_6 21052007.wiff (Nan..

Max. 2.7e6cps.

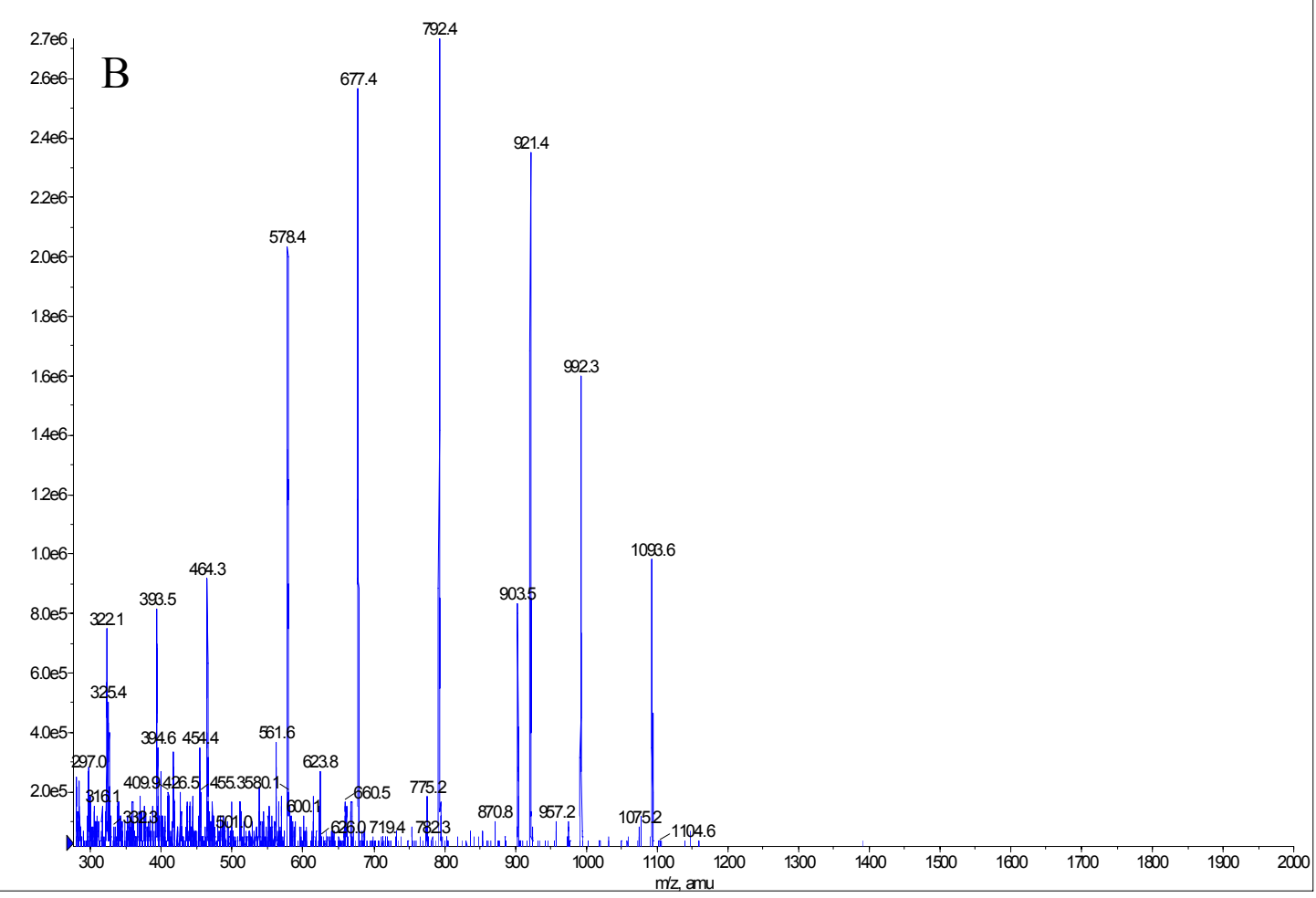

\begin{tabular}{|c|c|c|c|c|c|c|c|c|c|c|c|c|c|c|}
\hline \multicolumn{5}{|c|}{ Group Report } & \multicolumn{3}{|c|}{ Protein Summary } & \multicolumn{7}{|c|}{ Peptide Summary } \\
\hline- & N Unused & $\begin{array}{l}\text { Total } \\
\text { Protse }\end{array}$ & Accession & Protein Name & Speecies & Conf & Sequence & Mod & Zone & dMass & precMW & $\mathrm{z}$ sc & Dst & Locus \\
\hline- & 8.17 & 8.17 & $\begin{array}{l}\text { G3PB_TOBAC } \\
\text { (P09044) }\end{array}$ & $\begin{array}{l}\text { Glyceraldehyde-3-Phosphate dehydrogenase } \\
\text { B.Chloroplast Precursor (EC 1.2.1.13)(NADP- } \\
\text { dependent glyc }\end{array}$ & & 73 & AAALNIVPTSTGAAK & & & -0.05 & 1383.72 & \begin{tabular}{|l|l|}
2 & 23 \\
\end{tabular} & 7 & 1.1.307.5 \\
\hline & 0.59 & 6.70 & $\begin{array}{l}\text { G3PB_ARATH } \\
\text { (P25857) }\end{array}$ & $\begin{array}{l}\text { Glyceraldehyde-3-Phosphate dehydrogenase B. } \\
\text { Chloroplast Precursor (EC 1.2.1.13)(NADP- } \\
\text { dependent glyc }\end{array}$ & & 48 & AVSLVLPQLK & & & -0.05 & 1066.83 & 220 & 6 & 1.1.412.4 \\
\hline
\end{tabular}

Fig. (4). MS/MS spectrum from MALDI-TOF MS analysis (A) of protein 37. Detail of the MS/MS spectrum (B) of the doubly charged ion at $\mathrm{m} / \mathrm{z} 632.44$ from LC-MSMS analysis. 
even under water limitation, although the exact mechanism of tolerance remains to be investigated. In other plant systems changes in a number of proteins during stress application have been observed, with an increasing number of upregulated spots compared with down-regulated ones throughout stress progression [32]. We have not seen the typical increase of stress-related proteins such as those involved in ROS handling and protein stability and folding [28]. These could be explained in terms of the length and/or intensity of the stress, our studies being focused on early responses (4 and 10 days) under light stress. However it clearly affected the susceptible genotype.

\section{ACKNOWLEDGEMENTS}

This work has been supported by the Junta de Andalucía and the University of Córdoba (AGR-164, Agricultural and Plant Biochemistry Research group).

\section{REFERENCES}

[1] Cánovas, F. M.; Dumas-Gaudot, E.; Recorbet, G.; Jorrín, J.; Mock, H.-P.; Rossignol, M. Proteomics, 2004, 4, 285 - 298.

[2] Jorrín, J. V.; Rubiales, D.; Dumas-Gaudot, E.; Recorbet, G.; Maldonado, A. M.; Castillejo, M. A.; Curto, M. Euphytica, 2006, 147, 37-47.

[3] Rossignol, M.; Peltier, J.-B.; Mock, H.-P.; Matros, A.; Maldonado, A. M.; Jorrín, J. Proteomics, 2006, 6, 5529-5548.

[4] Cantamutto, M.; Poverene, M. Field Crops Res., 2007, 101, 133144.

[5] Mahajan, S.; Tuteja, N. Arch. Biochem. Biophys., 2005, 444, 139158.

[6] Manivannan, P.; Abdul Jaleel, C.; Sankar, B.; Kishorekumar, A.; Somasundaram, R.; Lakshmanan, R.; Panneerselvam, G.M.A. Colloids Surf., B, 2007, 59, 141-149.

[7] Riccardi, F.; Gazeau, P.; Jacquemot, M.-P.; Vincent, D.; Zivy, M. Plant Physiol. Biochem., 2004, 42, 1003-1011.

[8] Miller, J. F.; Fick, G. N. In Sunflower Technology and Production, Schneiter, A. A., Ed.; USA, 1997; pp 441-495.

[9] Correia, M. J.; Osorio, M. L.; Osorio, J.; Barrote, I.; Martins, M.; David, M. M. Environ. Exp. Bot., 2006, 58, 75-84.

[10] Kiani, S. P.; Grieu, P.; Maury, P.; Hewezi, T.; Gentzbittel, L.; Sarrafi, A. Theor. Appl. Genet., 2007, 114, 193-207.

[11] Echevarría-Zomeño, S.; Pérez-de-Luque, A.; Jorrín, J.; Maldonado, A. M. J. Exp. Bot., 2006, 57, 4189-200.

[12] Hoagland, D. R.; Arnon, D. I. California Agricul. Experiment. Station Circ., 1950, 347, 1-39.
[13] Curto, M.; Camafeita, L. E.; López, J. A.; Maldonado, A. M.; Rubiales, D.; Jorrín, J. Proteomics, 2006, 6, S163-S174.

[14] Görg, A.; Postel, W.; Weser, J.; Günther, S.; Strahler, J. R.; Hanash, S. M.; Somerlot, L. Electrophoresis, 1987, 8, 45-51.

[15] Mathesius, U.; Keijzers, G.; Natera, S. H. A.; Djordjevic, M. A.; Rolfe, B. G. Proteomics, 2001, 1, 1424-1440.

[16] Schevchenko, A.; Wilm, M.; Vorm, O.; Mann, M. Anal. Chem., 1996, 68, 850-858.

[17] Gobom, J.; Schuerenberg, M.; Mueller, M.; Theiss, D.; Lehrach, H.; Nordhoff, E. Anal. Chem., 2001, 3, 434-438.

[18] Jorge, I.; Navarro, R. M.; Lenz, C.; Ariza, D.; Porras, C.; Jorrín, J. Proteomics, 2005, 5, 222-234.

[19] Castillejo, M. A.; Amiour, N.; Dumas-Gaudot, E.; Rubiales, D.; Jorrín, J. V. Phytochemistry, 2004, 65, 1817 - 1828.

[20] Jorge, I.; Navarro, R. M.; Lenz, C.; Ariza, D.; Jorrín, J. V. Proteomics, 2006, 6, Suppl 1: S207-14.

[21] Thiellement, H.; Zivy, M.; Plomion, C. J. Chromatogr. B, 2002, 782, 137-149.

[22] Basu, P. S.; Sharma, A.; Garg, I. D.; Sukumaran, N. P. Environ. Exp. Bot., 1999, 42, 25-39.

[23] Dalla Costa, L.; Delle Vedov, G.; Gianquinto, G.; Giovanardi, R.; Peressotti, A. Potato Res., 1997, 40, 19-34.

[24] Dungey, N. O.; Davies, D. D. Planta 1982, 154, 435-440.

[25] Hajheidari, M.; Abdollahian-Noghabi, M.; Askari, H.; Heidari, M.; Sadeghian, S.; Ober, E. S.; Salekdeh, G. H. Proteomics, 2005, 5, 950-960.

[26] Salekdeh, G. H.; Siopongco, J.; Wade, L. J.; Ghareyazie, B.; Bennett, J. Proteomics, 2002, 2, 1131-1145.

[27] Ali, G. M.; Komatsu, S. J. Proteome Res., 2006, 5, 396-403.

[28] Guy, C. L. Ann. Rev. Plant Physiol. and Mol. Biol., 1990, 41, 187223.

[29] Hajheidari, M.; Eivazi, A.; Buchanan, B.B.; Wong, J.H.; Majidi, I.; Salekdeh, G.H. J. Proteome Res., .2007, 6, 1451-60.

[30] Plomion, C.; Lalanne, C.; Claverol, S.; Meddour, H.; Kohler, A.; Bogeat-Triboulot, M.-B.; Barre, A.; Le Provost, G.; Dumazet, H.; Jacob, D.; Bastien, C.; Dreyer, E.; de Daruvar, A.; Guehl, J.-M.; Schmitter, J.-M.; Martin, F.; Bonneu, M. Proteomics, 2006, 6, 6509-6527.

[31] Vincent, D.; Lapierre, C.; Pollet, B.; Cornic, G.; Negroni, L.; Zivy, M. Plant Physiol., 2005, 137, 949-960.

[32] Leone, A.; Costa, A.; Tucci, M.; Grillo, S. Physiol. Plant. 1994, 92, 21-30.

[33] Abbasi, F. M.; Komatsu, S. Proteomics, 2004, 4, 2072-2081.

[34] Majeau, N.; Arnoldo, M. A.; Coleman, J. R. Plant Mol. Biol., 1994, 25, 377-385.

[35] Raines, C.; Horsnell, P. R.; Holder, C.; Lloyd, J. C. Plant Mol. Biol., 1992, 20, 1143-1148.

[36] Ko, K.; Granell, A.; Bennett, J.; Cashmore, A. R. Plant Mol. Biol., 1990, 14, 217-227.

[37] Cherniad'ev, I.; Monakhova, O. F. Prikl. Biokhim. Mikrobiol., 2001, 37, 706-712. 